\title{
Neosporidesmium subramanianii sp. nov. from Vietnam
}

\author{
Mel'nik VA ${ }^{1}$, Popov ES ${ }^{1,2}$ and Braun $\mathrm{U}^{3}$ \\ ${ }^{1}$ Laboratory of the Systematics and Geography of Fungi, Komarov Botanical Institute, Russian Academy of Sciences, \\ Professor Popov Street 2, St. Petersburg 197376, Russia \\ ${ }^{2}$ Joint Vietnamese-Russian Tropical Research and Technological Centre, Nguyen Van Huyen, Nghia Do, Cau Giau, \\ Hanoi, Vietnam \\ ${ }^{3}$ Martin Luther University, Institute of Biology, Department of Geobotany and Botanical Garden, Herbarium, Neuwerk \\ 21, 06099 Halle (Saale), Germany
}

Mel'nik VA, Popov ES, Braun U 2016 - Neosporidesmium subramanianii sp. nov. from Vietnam. Mycosphere 7(2), 148-153, Doi 10.5943/mycosphere/7/2/6

\begin{abstract}
The new species Neosporidesmium subramanianii, based on material collected in Vietnam on dead leaves of Saccharum spontaneum, is described, illustrated, compared with morphologically similar species, and an updated key to the species of Neosporidesmium is also provided.
\end{abstract}

Key words - ascomycetes - asexual morph - South East Asia - synnematous hyphomycetes taxonomic novelty

\section{Introduction}

Vietnam is a tropical country with high but little explored fungal diversity. Within the scope of a research program of the Vietnamese-Russian Tropical Research and Technological Centre, in recent years numerous fungi of different taxonomic groups have been collected and published in a series of papers (Mel'nik 2011, 2012a, b, Mel'nik \& Braun 2013, Mel'nik et al. 2012, 2013, 2014, 2015). Recently a synnematous hyphomycete was collected on dead leaves of Saccharum spontaneum, critical morphological examination revealed it to be an undescribed species of Neosporidesmium Mercado \& J. Mena (Mercado \& Mena 1988). Attempts to cultivate this fungus in vitro, in order to be able to carry out molecular analyses, failed, but due to striking morphological characters and clear differences to all similar and comparable species it is justified to introduce a new species of Neosporidesmium.

\section{Materials \& Methods}

Fresh samples collected in the course of field trips in Vietnam were dried at room temperature. The collections were later examined in distilled water and photographed using a Zeiss microscope, Stemi 2000CS, and Axio Imager A1 equipped with Nomarski differential interference contrast optics. Measurements of 30 conidia and other structures have been made whenever possible at a magnification of $\times 1000$, and the $95 \%$ confidential intervals were determined and extreme values were given in parentheses. The identification of the new species was accomplished through comparison with descriptions of other species hitherto assigned to Neosporidesmium. Type material is deposited at LE. 


\section{Results}

Neosporidesmium subramanianii Melnik, E.S. Popov \& U. Braun, sp. nov. Fig. 1 MycoBank, MB816352

Etymology - named in memoriam of an outstanding Indian mycologist, C.V. Subramanian (1924-2016).

Diagnosis - Morphologically similar to N. macrosporum which, however, differs from $N$. subramanianii in having broader conidiophores, $4.5-8 \mu \mathrm{m}$ wide, much larger conidiogenous cells, 23.5-34.5 × 7-9.5(-12.5) $\mu \mathrm{m}$, and longer obclavate conidia, 108-250 $\mu \mathrm{m}$, gradually attenuated towards the tip, with long attenuated terminal portion.

Typus - VIETNAM, Dong Nai Province, Tan Phu District, Cat Tien National Park (Nam Cat Tien Sector), right side of Dong Nai river close to the Park's Headquarter, $11^{\circ} 25^{\prime} 31.9^{\prime \prime} \mathrm{N}$, 107²5'45.9"E, on dead leaves of Saccharum spontaneum, 17 Dec. 2014, E.S. Popov (LE 264614 holotype).

Colonies on natural substrate effuse, dark brown and hairy. Mycelium superficial and partly immersed in the substratum; hyphae septate, brown, thin-walled, smooth. Conidiomata synnematous, solitary, erect, dark brown to black, main portion more or less cylindrical to gradually attenuated towards the apex, 600-1200 $\mu \mathrm{m}$ long, 45-80 $\mu \mathrm{m}$ wide below, i.e. just above the basal part immersed in the substrate, which is discoid or even rhizoid, up to $120 \mu \mathrm{m}$ diam, 24$30 \mu \mathrm{m}$ wide near the apex. Conidiophores macronematous, unbranched, septate, wall $\leq 1 \mu \mathrm{m}$ thick, smooth, brown to dark brown, 600-1200 $\mu \mathrm{m}$ long and 4-5 $\mu \mathrm{m}$ wide. Conidiogenous cells spread along the upper half to two-third of the synnemata, sometimes up to $80 \%$ of the upper part of the synnemata with laterally splaying out conidiogenous cells, integrated, terminal, monoblastic, determinate, short subcylindrical-conical, doliiform to lageniform 8-13 $\times 3-3.5 \mu \mathrm{m}$, brown to dark brown, thin-walled, smooth. Conidia holoblastic, solitary, dry, acrogenous, straight to somewhat curved, broadly obclavate, (80-)90-112(-120) × 10-13(-14) $\mu \mathrm{m},(8-) 9-15$-distoseptate, smooth, brown, with thin outer and thick inner wall layer giving rise to reduced cell lumina, apex obtuse, broadly rounded, with obconically truncate base, 3-3.5 $\mu \mathrm{m}$ wide, a trapezoidal portion of the base usually strongly pigmented, dark brown. Conidial secession schizolytic.

Known distribution - hitherto only known from the type locality.

\section{Discussion}

Neosporidesmium subramanianii is the third species of the genus reported from Vietnam. Mel'nik \& Braun (2013) described N. vietnamense Melnik \& U. Braun based on synnemata on twigs of an unidentified tree collected by Yu. Novozhilov in the Vietnamese Dong Nai province in 2011. A second record refers to N. maestrense Mercado \& J. Mena on the rachis of Calamus sp. (Arecaceae) collected by A.V. Alexandrova in the Vietnamese Dak Lak province in 2013 (Mel'nik et al. 2014). Mel'nik \& Braun (2013) provided a detailed discussion of the current wide generic concept of Neosporidesmium. This genus was introduced for synnematous hyphomycetes characterized by having percurrently proliferating conidiogenous cells forming distinctly swollen subsequent cells and scolecosporous, distoseptate conidia (Mercado \& Mena 1988). Neosporidesmium antidesmatis Jian Ma \& X. G. Zhang (Ma et al. 2011) and N. microsporum W.P. $\mathrm{Wu}$ (Wu \& Zhuang 2005) are two additional species forming comparable percurrent proliferations. Furthermore, several species with monoblastic, determinate, i.e. non-proliferating conidiogenous cells have been assigned to Neosporidesmium [N. appendiculatum I.B. Prasher \& R.K. Verma (Prasher \& Verma 2015b), N. diaoluoshanense Xiang Y. Li \& X.G. Zhang (Li et al. 2015), N. macrosporum I.B. Prasher \& R.K. Verma (Prasher \& Verma 2015a), N. malloti Jian Ma \& X.G. Zhang (Ma et al. 2011), N. sinense W.P. Wu (Wu \& Zhuang 2005), and N. xanthophylli Jian Ma \& X.G. Zhang (Ma et al. 2011)]. 


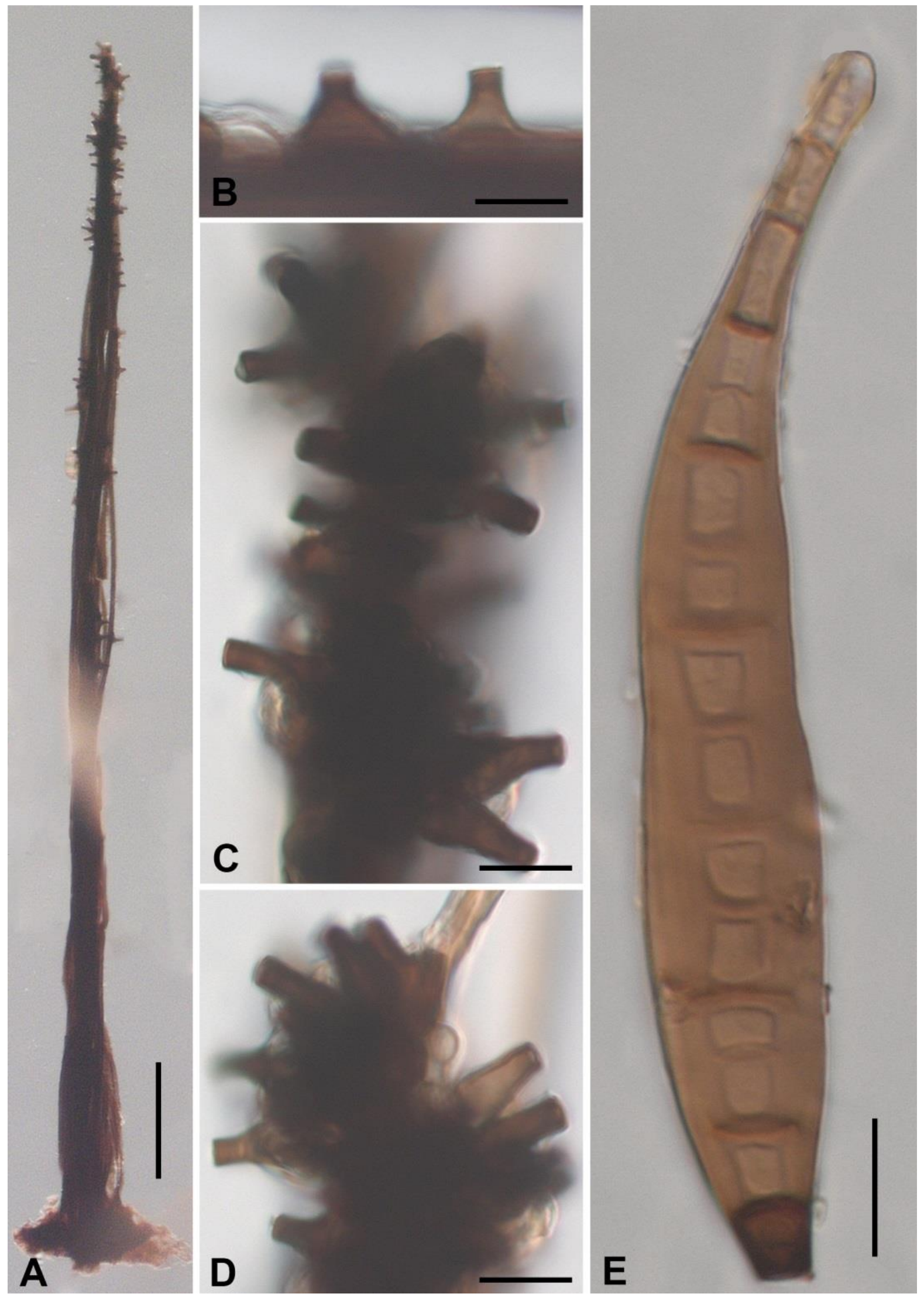

Fig. 1 - Neosporidesmium subramanianii (holotype). A Synnema. B, C, D conidiogenous cells. E conidium. - Scale bars: $\mathrm{A}=100 \mu \mathrm{m}, \mathrm{B}, \mathrm{C}, \mathrm{D}=10 \mu \mathrm{m}$. 
However, the most drastic emendation to the genus Neosporidesmium goes back to the description of $N$. micheliae Y.D. Zhang \& X.G. Zhang (Zhang et al. 2011), a species characterized by having euseptate conidia. The two species of Neosporidesmium with euseptate conidia, $N$. micheliae and $N$. vietnamense, are possibly not congeneric with the type species of the genus. Besides euseptate conidia, the two species differ from distoseptate species in having uniformly pigmented conidia, i.e. without dark brown conidial base. Shenoy et al. (2006) published results of comprehensive DNA sequence analyses of a wide range of taxa of the Sporidesmium Link complex suggesting that Sporidesmium, Ellisembia Subram. and other segregated genera are not monophyletic. Particular species of these genera are phylogenetically placed in two major classes of ascomycetes, i.e. Dothideomycetes and Sordariomycetes. A single sequence referred to as Neosporidesmium sp. clustered in the Dothideomycetes adjacent to Sporidesmium australiense M.B. Ellis. However, as long as molecular data for N. maestrense, the type species, and the other species concerned are not available, we prefer to refrain from any taxonomic conclusions and changes on generic level. Applying the currently accepted morphological concept of Neosporidesmium, the new species from Vietnam can be readily assigned to the genus Neosporidesmium. Basic characters like conidiomata, conidiogenous cells, and septation of conidia agree well with the concept of this genus. It pertains to a group of species characterized by having monoblastic, determinate (non-proliferating) conidiogenous cells combined with distoseptate conidia. Neosporidesmium macrosporum is the only comparable species, which however differs in having much wider conidiophores, much larger conidiogeous cells, and significantly longer conidia, gradually attenuated towards the tip, with long attenuated terminal portion (see diagnosis). Species currently allocated to Neosporidesmium are keyed out in the following updated key based on an older version published by Mel'nik \& Braun (2013).

\section{Updated key to Neosporidesmium species}

1. Conidia euseptate, conidial base more or less concolorous with body, not darker brown ....... 2 Conidia distoseptate, base of the conidia around the hila strongly pigmented, darker brown . 3

2. Synnemata (380-)500-1430 $\mu \mathrm{m}$ long, 40-45 $\mu \mathrm{m}$ wide below; conidiophores $2-2.5 \mu \mathrm{m}$ wide; conidia (75-)80-96(-110) $\times 11-13.5 \mu \mathrm{m}$, wall smooth to somewhat rough, surface at least not quite even, rostrate apex subhyaline

N. vietnamense

- $\quad$ Synnemata up to $530 \mu \mathrm{m}$ long, 20-30 $\mu \mathrm{m}$ wide below; conidiophores 4.5-6.5 $\mu \mathrm{m}$; conidia $40-60 \times 8.5-11 \mu \mathrm{m}$, wall smooth, apex not distinctly rostrate and pale brown .... N. micheliae

3. Conidiogenous cells percurrently proliferating, with distinct constriction (cells doliiform-

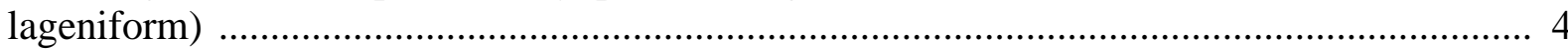

- $\quad$ Conidiogenous cells monoblastic, determinate, without any proliferations ........................... 6

4. Conidia distinctly rostrate, rostrum hyaline or sub-hyaline ............................ N. antidesmatis

- Conidia non-rostrate ......................................................................................................... 5

5. Conidia 45-67 $\times 6-7 \mu \mathrm{m}, 6-7$-distoseptate ................................................. N. microsporum Conidia 55-100 × 15-19 $\mu \mathrm{m}, 8-12$-distoseptate ............................................. N. maestrense

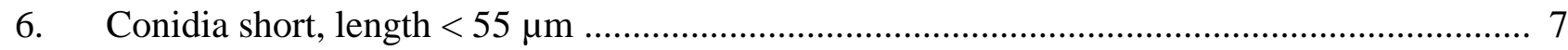

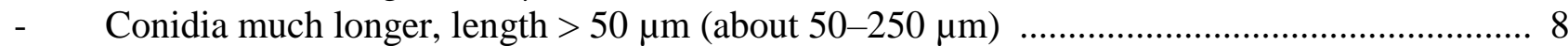

7. Conidia 22.5-33.5 $\times 7-9 \mu \mathrm{m}, 6-7$-distoseptate, apex pale brown and not distinctly rostrate N. malloti

Conidia 33.5-51.5 × 12-14 $\mu \mathrm{m}, 6$-10-distoseptate, with distinct, hyaline or sub-hyaline rostrum, $11-19 \mu \mathrm{m}$ long N. xanthophylli 
8. Conidia distinctly rostrate, with long, filiform, hyaline to sub-hyaline beak

Beak lacking or conidia gradually attenuated towards the tip, but apex concolourous with the conidial body or somewhat paler, or apex of conidia distinctly swollen, with globose mucilaginous sheath or short branchlets

9. Synnemata $80-110 \mu \mathrm{m}$ wide at the base; conidiogenous cells consistently monoblastic, determinate, without any proliferations; conidia 12-15 $\mu \mathrm{m}$ wide, 10-11-distoseptate

N. sinense

Synnemata 30-50 $\mu \mathrm{m}$ wide at the base; conidiogenous cells without or with a single percurrent proliferation, but cells always lageniform-doliiform; conidia 7.5-9 $\mu \mathrm{m}$ wide, $11-$ 15-distoseptate N. antidesmatis

10. Conidial apex with short branchlets (appendages) or with a globose mucilaginous sheath .. 11 Apex simple, obtuse, at most slightly swollen, but without any appendages or mucilaginous sheaths

11. Synnemata (615-)850-4700 $\mu \mathrm{m}$ long, and 35-145 $\mu \mathrm{m}$ wide, conidiogenous cells numerous, spread along almost the whole length of synnemata, from apex to base; conidial apex with short appendages, conidia 17-19 $\mu \mathrm{m}$ wide, 9-15-distoseptate $N$. appendiculatum

- Synnemata up to $605 \mu \mathrm{m}$ long, and 40-60 $\mu \mathrm{m}$ wide; conidiogenous cells not numerous, confined to the apical part of the synnemata; conidial apex with globose, mucilaginous sheath, 10.5-13.5 $\mu \mathrm{m}$ diam, conidia $10.5-13.5 \mu \mathrm{m}$ wide, 8-11-distoseptate

N. diaoluoshanense

12. Conidiophores 4.5-8 $\mu \mathrm{m}$ wide; conidiogenous cells doliiform, 23.5-34.5 $\times 7-9.5(-12.5) \mu \mathrm{m}$; conidia 108-250 $\mu \mathrm{m}$ long, obclavate, gradually attenuated towards the tip, attenuated terminal portion long N. macrosporum Conidiophores 4-5 $\mu \mathrm{m}$; conidiogenous cells subcylindrical-conical, doliiform to lageniform, 8-13 × 3-3.5 $\mu \mathrm{m}$; conidia (80-)90-112(-120) $\mu \mathrm{m}$ long, obclavate, but stout, attenuated terminal portion short N. subramanianii

\section{Acknowledgements}

The present study was carried out within the scope of the institutional research project (no. 01201255603) of the Komarov Botanical Institute of the Russian Academy of Sciences. We gratefully acknowledge the technical support provided by The Core Facility Center "Cell and Molecular Technologies in Plant Science" of the Komarov Botanical Institute, Russian Academy of Sciences, St. Petersburg, Russia. The authors are much obliged to the administration of the Joint Vietnamese-Russian Tropical Research and Technological Centre and to the Cat Tien National Park for the assistance in the organization of field work. Expeditions and laboratory work were supported by the Program Ecolan-1.2 of the Joint Vietnamese- Russian Tropical Scientific and Technological Centre.

\section{References}

Li XY, Liu SY, Zhang XG. 2015 - A new species of Neosporidesmium from Hainan, China. Mycotaxon 130, 307-310.

Ma J, Wang Y, Ma LG, Zhang YD, Castañeda-Ruíz RF, Zhang XG. 2011 - Three new species of Neosporidesmium from Hainan. Mycological Progress 10, 157-162.

Mel'nik VA. 2011 - Anamorphic fungi of Vietnam. I. Mikologiya i Fitopatologiya 45, 323-331. (In Russian) 
Mel'nik VA. 2012a - A new species of Ardhachandra (hyphomycetes) from Vietnam. Mycosphere 3, 922-924.

Mel'nik VA. 2012b - Phaeoisariopsis vietnamensis sp. nov. and P. clematidis (hyphomycetes) from Vietnam. Mycosphere 3, 957-960.

Mel'nik VA, Braun, U. 2013 - Atractilina alinae sp. nov. and Neosporidesmium vietnamense sp. nov. - two new synnematous hyphomycetes from Vietnam. Mycobiota 3, 1-9.

Mel'nik VA, Novozhilov YuK, Popov ES, Alexandrova AV. 2012 - Anamorphic fungi of Vietnam. II. Mikologiya i Fitopatologiya 46, 347-356.

Mel'nik VA, Braun U, Alexandrova AV. 2013 - Dactylaria mucoglobifera sp. nov. - a new species from Vietnam. Schlechtendalia 25, 49-52.

Mel'nik VA, Alexandrova AV, Braun U. 2014 - Two new species and new records of hyphomycetes from Vietnam. Mycosphere 5, 591-600.

Mel'nik VA, Alexandrova AV, Zmitrovich IV, Braun U, Popov ES. 2015 - First record of Hyphobasidiofera malaysiana (Basidiomycota) from Vietnam. Mycobiota 5, 1-5.

Mercado SA, Mena PJ. 1988 - Nuevos o raros hifomicetes de Cuba. Acta Botanica Cubana 59, 16.

Prasher IB, Verma RK. 2015a - Some new and interesting hyphomycetes from North-Western Himalayas, India. Nova Hedwigia 100, 269-277.

Prasher IB, Verma RK. 2015b - Neosporidesmium appendiculatus sp. nov. from North-Western India. Mycological Progress 14, Article 87, 1-6.

Shenoy BD, Jeewon R, Wu WP, Bhat DJ, Hyde KD. 2006 - Ribosomal and RPB2 sequence analyses suggest that Sporidesmium and morphologically similar genera are polyphyletic. Mycological Research 110, 916-929.

Wu WP, Zhuang WY. 2005 - Sporidesmium, Endophragmiella and related genera from China. Fungal Diversity Research Series 15, 1-351.

Zhang YD, Ma J, Ma LG, Castañeda-Ruíz RF, Zhang XG. 2011 - New species of Phaeodactylidium and Neosporidesmium from China. Sydowia 63, 125-130. 